\title{
Uprawnienia kobiet na gruncie prawa pracy oraz ubezpieczeń społecznych
}

Uprawnienia pracownicze przenikają się bardzo często z uprawnieniami wynikającymi z podlegania ubezpieczeniom społecznym oraz ubezpieczeniu zdrowotnemu. Zajmując się prawami pracownic nie sposób nie przyjrzeć się urlopowi macierzyńskiemu, rodzicielskiemu, wychowawczemu, jak również innym uprawnieniom wynikającym z k.p.

Ciężarnym pracownicom gwarantuje się szereg uprawnień, które są nakierunkowane na pomoc i wsparcie zarówno samej kobiety, jak i nowonarodzonego dziecka. Zarówno prawo pracy, jak i prawo ubezpieczeń społecznych wyodrębniają stan jakim jest ciąża. Precyzując, bezpośrednio z ostatnim etapem ciąży związany jest udzielany w myśl prawa pracy - urlop macierzyński, natomiast zgodnie z prawem ubezpieczeń społecznych - zasiłek macierzyński za okres urlopu macierzyńskiego. Na pracodawcę nałożone są liczne obowiązki związane z szeroko pojętą ochroną macierzyństwa. Pracodawca jest zobowiązany udzielać pracownicy przerw na karmienie, dwóch dni w roku na opiekę nad dzieckiem do lat 14, zwolnień w związku z opieką nad chorym dzieckiem, a przede wszystkim udzielić pracownicy obligatoryjnego urlopu macierzyńskiego. Ponadto pracodawca nie może zatrudniać pracownicy w warunkach szkodliwych dla kobiet w ciąży oraz nie może zatrudniać jej w porze nocnej i godzinach nadliczbowych ${ }^{2}$.

Zgodnie z rozporządzeniem Rady Ministrów z dnia 10 września 1996 roku w sprawie wykazu prac wzbronionych kobietom ${ }^{3}$ zarządzono, że ani kobiet w ciąży ani w okresie karmienia nie wolno zatrudniać m.in. do prac w których najwyższe obciążenie fizyczne przekracza $2900 \mathrm{~kJ}$ na zmianę roboczą, ponadto nie wolno zatrudniać ich do pracy w pozycji wymuszonej oraz do pracy w pozycji stojącej przekraczającej 3 godziny w czasie zmiany roboczej. Dodatkowo, kobietom w ciąży nie wolno obsługiwać monitorów ekranowych powyżej 4 godzin na dobę, a kobietom już w okresie karmienia - pracować przy otwartych źródłach promieniowania jonizującego. W przytoczonym rozporządzeniu występuje jeszcze szereg innych zakazów, które nakładają na pracodawców rozliczne obowiązki w celu zapewnienia pracownicom największego bezpieczeństwa. Wydaje się być jasnym, iż ustawodawcy zależy na zapewnieniu kobietom najbardziej komfortowych warunków dla ich zdrowia oraz zdrowia ich dzieci.

\footnotetext{
${ }^{1}$ Magister, Uniwersytet Łódzki, Wydział Prawa i Administracji.

${ }^{2}$ U. Jackowiak, Sytuacja pracownicza kobiet, Lex 1994.

${ }^{3}$ Rozporządzenie Rady Ministrów z dnia 10 września 1996 r. w sprawie wykazu prac wzbronionych kobietom, Dz.U. z 1996 r. Nr 114, poz. 545 ze zm.
} 
Jak wynika z art. 178 k.p. na pracodawcę został nałoży obligatoryjny zakaz zatrudniania pracownicy w ciąży w godzinach nadliczbowych oraz w porze nocnej. Natomiast w przypadku pracownika posiadającego pod opieką dziecko do lat 4 wymagana jest jego zgoda na zatrudnienie w porze nocnej, jak i w godzinach nadliczbowych.

Pracownicom karmiącym dzieci piersią przysługują dwie przerwy w pracy, każda po 30 minut, które są wliczane do czasu pracy. W przypadku pracownic karmiących równocześnie więcej niż jedno dziecko, przerwy te wydłużane są do 45 minut. Zgodnie z art. 187 § 2 k.p. kobietom karmiącym piersią, które zatrudnione są w wymiarze czasu pracy krótszym niż 4 godziny dziennie taka przerwa na karmienie nie przysługuje. Inaczej jest w sytuacji, gdy czas ich pracy nie przekracza 6 godzin dziennie - w takim przypadku mają one prawo do jednej przerwy na karmienie. Możliwym jest, aby dla pracownicy pracującej 8 godzin dziennie udzielić dwóch przerw na karmienie łącznie, jednakże wymagane jest w takim przypadku złożenie odpowiedniego wniosku pracodawcy. Jak wynika z praktyki, zazwyczaj pracownice wnioskują o dwie przerwy łącznie mające miejsce w ostatniej godzinie pracy. Ważny jest fakt, że za przerwy na karmienie przysługuje pracownicy wynagrodzenie w takiej wysokości jakie przysługiwałoby jej gdyby wykonywała w tym czasie pracę. Należy podkreślić, że w k.p. zostało doprecyzowane, że tylko pracownicom karmiącym dziecko naturalnie należy się prawo do takiej przerwy. Ponadto ustawodawca nie doprecyzował czasu w jakim przysługuje uprawnienie do przerw na karmienie. To niedookreślenie sugerowałoby, iż przerwa taka przysługuje pracownicy w całym okresie karmienia dziecka piersią, jednakże powinno być to udokumentowane przez lekarza na zaświadczeniu lekarskim - zważywszy na fakt, że często jest to kwestia indywidualna każdej kobiety4

Kolejnym uprawnieniem ułatwiającym kobietom pogodzenie obowiązków rodzinnych i zawodowych jest zwolnienie od pracy dla pracownicy, która wychowuje dziecko w wieku do 14 roku życia. Zwolnienie to przysługuje w wymiarze 2 dni lub 16 godzin (wymiar godzinowy ma zastosowanie dla pracowników zatrudnionych w niepełnym wymiarze, zwolnienie takie jest ustalane w sposób proporcjonalny do wymiaru czasu pracy). Zgodnie z art. 188 § 2 k.p. sposób wykorzystania zwolnienia w danym roku kalendarzowym jest uzależniony od decyzji pracownika, który każdorazowo na początku roku kalendarzowego składa wniosek o udzielenie zwolnienia od pracy w celu opieki nad dzieckiem. Bardzo ważnym jest podkreślenie w tym przypadku, iż takie prawo posiada zarówno zatrudniona matka dziecka, jak i zatrudniony ojciec lub też odpowiednio opiekunowie dziecka. Jeżeli oboje rodzice pozostają w stosunku pracy, to z powyższego zwolnienia może skorzystać tylko jedno z nich.

${ }^{4}$ U. Jackowiak, op. cit. 
W zakresie prawa pracy, tytuł do ubezpieczeń nie jest przypisany tylko do pracownika jako osoby pozostające $\mathrm{w}$ stosunku pracy, ale również występuje z nim bardzo często tytuł związany z pobieraniem zasiłku macierzyńskiego (tj. urlop macierzyński, urlop na warunkach urlopu macierzyńskiego, urlop rodzicielski, urlop ojcowski) lub związany z wykorzystaniem urlopu wychowawczego. W sytuacji, w której powyższe okoliczności zachodzą podczas trwania stosunku pracy, następuje zmiana tytułu ubezpieczenia pod jaki podlega pracownik. Przykładowo, odnosząc się do łącznego wykonywania pracy i przebywania na urlopie rodzicielskim - pracownik podlega wtedy obligatoryjnie ubezpieczeniu emerytalnemu oraz rentowemu z obu tych tytułów ${ }^{5}$.

Zasiłek opiekuńczy jest to zasiłek wypłacany przez Zakład Ubezpieczeń Społecznych, który przysługuje wszystkim osobom, które podlegają ubezpieczeniu chorobowemu, niezależnie czy obowiązkowo czy dobrowolnie. Ważnym jest, iż prawo do zasiłku opiekuńczego przysługuje bez okresu wyczekiwania, czyli skutkuje już od pierwszego dnia podlegania ubezpieczeniu chorobowemu. Jednakże głównym czynnikiem, który należy wykazać, aby zasiłek został przyznany jest fakt, że $\mathrm{w}$ danym okresie nie ma żadnego innego członka rodziny, który mógłby sprawować opiekę we wnioskowanym czasie. Zasiłek opiekuńczy jest przyznawany w trzech przypadkach sprawowania opieki:

- nad dzieckiem do 8 roku życia w określonych przez ustawodawcę przypadkach,

- nad chorym dzieckiem do 14 roku życia,

- nad innym chorym członkiem rodziny.

Należy zwrócić uwagę, iż w przypadku dzieci zasiłek przysługuje zarówno matce i ojcu dziecka, przy czym zasiłek może być wypłacony tylko jednemu z nich, czyli tylko jeden z rodziców może złożyć wniosek o przyznanie świadczenia. Idąc naprzeciw zmianom społecznym ustawodawca nadał również prawo do zasiłku z tytułu opieki nad dzieckiem do lat 8 także rodzicom, którzy pozostają w nieformalnym związku.

Warto podkreślić, że naprawdę dużą zmianą była nowelizacja Kodeksu pracy z dnia 24 lipca 2014 r. (Dz.U. z 2015 r., poz. 1268), która weszła w życie 2 stycznia 2016 roku. Złączyła bowiem dodatkowy urlop macierzyński z urlopem rodzicielskim tworząc $w$ ten sposób jeden urlop nazwany bez zmian jako urlop rodzicielski. Pracownica ma możliwość wykorzystania kolejno następujących urlopów:

- urlop macierzyński,

- urlop rodzicielski,

- urlop wychowawczy.

${ }^{5}$ D. Dzienisiuk, Prawo pracy a prawo ubezpieczeń społecznych, Warszawa 2016, s. 158. 
Urlop macierzyński przysługuje pracownicy w okresie przed i po porodzie. Jest to urlop obowiązkowy, który przysługuje w wymiarze 20 tygodni. Przy czym pierwsze 6 tygodni urlopu pracownica może wykorzystać już przed planowanym terminem porodu, wtedy po narodzinach dziecka przysługuje jej pozostała część urlopu. Należy podkreślić, iż pracodawca nie może wymusić na pracownicy, aby ta wykorzystała część urlopu przed porodem. Decyzja o przejściu na urlop macierzyński jest jej indywidualną decyzją. Tym samym pracodawca nie może odmówić udzielenia powyższego urlopu ${ }^{6}$. Ważnym jest, iż kobieta nie ma obowiązku wykorzystać całych 20 tygodni urlopu. Po wykorzystaniu 14 tygodni urlopu, pracownica może zrezygnować z dalszej części urlopu i wrócić do pracy, ale tylko w przypadkach określonych w art. 180 § 4 k.p.:

- ojciec dziecka (pozostający w stosunku pracy oraz wychowujący dziecko) przejmie pozostałe 6 tygodni urlopu macierzyńskiego,

- ojciec dziecka (ubezpieczony, który przerywa swoją działalność zarobkową) przejmie pozostałą część urlopu.

Istotnym jest, iż w powyższych sytuacjach ojcu dziecka przysługuje odpowiednio zasiłek macierzyński za wykorzystaną przez niego część urlopu macierzyńskiego. Ustawodawca konstruując urlop macierzyński miał na celu zadbanie nie tylko o dobro dziecka, ale również zregenerowanie sił kobiety po urodzeniu dziecka. W sytuacji, gdy urlop macierzyński i zasiłek macierzyński mają być wypłacane za ten sam okres, prawo pracy nie ma konkretnych wskazań co do dokumentów stwierdzających przyznanie uprawnienia. Tutaj naprzeciw wychodzi prawo ubezpieczeń społecznych, które jasno wskazuje, że do wypłaty świadczenia wymagane jest przedłożenie aktu urodzenia dziecka. W doktrynie przyjmuje się więc wymagania zgodne z myślą prawa ubezpieczeń społecznych ${ }^{7}$.

W przypadku, gdy w trakcie trwania ciąży rozwiązaniu ulegnie terminowa umowa o pracę, wtedy umowa ta zostaje przedłużona aż do dnia porodu. Jednakże pracownica musi mieć ukończony pierwszy trymestr ciąży. Należy podkreślić, iż urlop macierzyński przysługuje tylko pracownikowi. W sytuacji, gdy umowa o pracę zostanie rozwiązana z upływem czasu na jaki była zawarta, pracownicy przestaje przysługiwać urlop macierzyński - jednakże zasiłek macierzyński przysługuje jej przez cały okres, przez jaki przebywałaby na urlopie macierzyńskim, a później rodzicielskim ${ }^{8}$. Zasiłek macierzyński jest to świadczenie wypłacane przez Zakład Ubezpieczeń Społecznych, które wynosi co do zasady $100 \%$ podstawy wymiaru zasiłku. Podstawą tą nazywa się ostatnie 12 miesięcy kalendarzowych, które poprzedzają miesiąc rozpoczęcia urlopu macierzyńskie-

\footnotetext{
${ }^{6}$ A. Matuszewska, K. Piecyk, Urlopy pracownicze i inne zwolnienia od pracy, Warszawa 2007, s. 153 .

${ }^{7}$ D. Dzienisiuk, op. cit., s. 329.

${ }^{8}$ M. Kuba, Podstawowe zasady realizacji prawa do urlopu wypoczynkowego, [w:] Urlopy Pracownicze, Z. Góral (red.), Warszawa 2016, s. 222.
} 
go. Warto podkreślić, iż nie trzeba u danego pracodawcy przepracować wspomnianych 12 miesięcy, aby nabyć prawo do wypłaty zasiłku macierzyńskiego. Jeżeli pracownica zatrudniona jest krócej, wtedy bierze się pod uwagę tylko pełne przepracowane miesiące i wylicza się w ten sposób przeciętne wynagrodzenie za podany okres. Jednakże, jeżeli pracownica nie przepracowała nawet całego miesiąca, wtedy bierzemy pod uwagę wynagrodzenie, jakie dostałaby gdyby przepracowała pełny miesiąc ${ }^{9}$.

Urlop rodzicielski przysługuje po wykorzystaniu urlopu macierzyńskiego. Jest to urlop fakultatywny, który przysługuje w wymiarze 32 tygodni (w przypadku urodzenia jednego dziecka) lub w wymiarze 34 tygodni (w przypadku urodzenia większej liczby dzieci). Warto zauważyć, że ogólny wymiar urlopu przysługuje łącznie matce i ojcu dziecka. Pracownik zobowiązany jest złożyć pracodawcy pisemny wniosek nie później niż na 21 dni przed rozpoczęciem urlopu rodzicielskiego. Warto podać dla wyjaśnienia, że termin 21 dni rozpoczyna bieg od następnego dnia po porodzie. Jeżeli jednak dwudziesty pierwszy dzień wypada w sobotę lub w dzień wolny od pracy, wtedy termin upływa w pierwszym dniu roboczym następującym po dniu wolnym ${ }^{10}$. Istotną możliwością, którą niektórzy rodzice wykorzystują jest fakt, że na urlopie rodzicielskim mogą oni przebywać jednocześnie, jednakże urlop ten nie może przekroczyć wymiaru. Urlop rodzicielski można wykorzystać maksymalnie w 4 częściach. Jeżeli jednak oboje nie będą chcieli od razu wykorzystać całego urlopu i powrócą do pracy, to pozostała część urlopu może zostać przez nich wykorzystana w późniejszym terminie. Jednak należy pamiętać, że możliwość ta obowiązuje tylko do końca roku kalendarzowego, w którym dziecko ukończy 6 lat ${ }^{11}$. Zgodnie $\mathrm{z}$ art. $182^{1 \mathrm{c}} \S 4$ k.p. każda część urlopu rodzicielskiego powinna mieć przynajmniej 8 tygodni. Wyjątki stanowią tylko takie sytuacje, które dotyczą pierwszej części urlopu rodzicielskiego lub gdy do wykorzystania pozostało mniej niż 8 tygodni.

Zgodnie z nowelizacją k.p. zmianie uległ czas przez który pracownica może łączyć urlop rodzicielski z wykonywaniem pracy. I tak od 2016 roku możliwe jest, aby łączyć urlop rodzicielski z wykonywaniem pracy maksymalnie przez 64 tygodni w przypadku narodzin jednego dziecka przy jednym porodzie lub 68 tygodni w przypadku urodzenia większej liczby dzieci przy jednym porodzie. W sytuacji, gdy pracownik chciałby wykorzystać urlop rodzicielski w powyższy sposób, zobowiązany jest złożyć pisemny wniosek pracodawcy, najpóźniej 21 dni przed planowanym rozpoczęciem pracy. Ważnym jest, aby pracownik określił we wniosku okres przez jaki zamierza łączyć urlop z wyko-

\footnotetext{
${ }^{9}$ Ibidem, s. 236.

${ }^{10} \mathrm{http}: / /$ zus.pl/files/Komentarz\%20chorobowy\%202016.pdf (dostęp: 01.11.2016).

${ }^{11} \mathrm{~K}$. Jaśkowski, E. Maniewska, Kodeks pracy. Tom I. Komentarz. Ustawy towarzyszace z orzecznictwem. Europejskie prawo pracy, wyd. X, Wolters Kluwer 2016.
} 
nywaniem pracy, jak również wymiar czasu pracy. Jeżeli pracownik nie będzie łączyć wykonywania pracy w niepełnym wymiarze czasu pracy z częścią urlopu rodzicielskiego, która powstała poprzez proporcjonalne wydłużenie - to okres o jaki urlop ulegnie wydłużeniu, będzie stanowić iloczyn liczby tygodni przez którą pracownik zamierza łączyć korzystanie z urlopu rodzicielskiego z pracą u pracodawcy udzielającego mu tego urlopu. Aby zobrazować obliczenie wydłużonego urlopu rodzicielskiego ZUS podaje przykład o następującej treści ${ }^{12}$ :

Pracownica, zatrudniona na $1 / 2$ etatu, w terminie 21 dni po porodzie wystapiła $z$ wnioskiem o udzielenie jej urlopu macierzyńskiego i urlopu rodzicielskiego w petnym wymiarze (32 tygodni). Przez caly okres urlopu rodzicielskiego łaczy ona wykonywanie pracy u pracodawcy udzielajacego tego urlopu w wymiarze 1/4 etatu. Pracownica $w$ trakcie wydtużonego urlopu nie będzie wykonywała pracy u pracodawcy, który udzielit tego urlopu. Udzielony pracownicy urlop rodzicielski ulega wydlużeniu o 8 tygodni (32 tygodnie x 1/4). Przez 32 tygodnie pracownicy przystuguje zasilek macierzyński $w$ kwocie zmniejszonej o połowe $(1 / 4: 1 / 2=1 / 2)$, natomiast przez okres 8 tygodni, o które ulega wydlużeniu urlop rodzicielski, pracownicy przystuguje zasiłek $w$ petnej miesięcznej kwocie, gdyż podczas wydłużonego urlopu rodzicielskiego nie wykonuje ona pracy.

Jeżeli jednak pracownica chciałaby wykorzystać urlop rodzicielski bez podejmowania pracy w trakcie jego trwania, wtedy ma 21 dni na złożenie pisemnego wniosku o udzielenie jej urlopu bezpośrednio po urlopie macierzyńskim. Nie ma również przeszkód, aby pracownica zrezygnowała z części lub nawet całości urlopu rodzicielskiego. Ponadto nie jest jej na to potrzebna zgoda pracodawcy ${ }^{13}$.

Urlop wychowawczy jest szczególnym rodzajem urlopu związanego z rodzicielstwem, ponieważ jest to urlop nieodpłatny. Wykorzystywany jest przez pracownice po urlopie rodzicielskim. Urlop wychowawczy przysługuje matce dziecka przez 36 miesięcy, przy czym 1 miesiąc należy wyłącznie do ojca dziecka - nie ma możliwości, aby ojciec dziecka zrzekł się przysługującego mu urlopu na rzecz matki dziecka. Należy podkreślić, że ta sama zasada działa również $\mathrm{w}$ drugą stronę. Jednakże należy szczególnie podkreślić, iż w trakcie urlopu wychowawczego nie przysługuje żaden zasiłek wypłacany przez ZUS. Jeżeli w trakcie tego urlopu ani matka ani ojciec dziecka nie posiadają innych tytułów do ubezpieczeń lub nie pobierają emerytury ani renty - wtedy budżet państwa przejmuje obowiązek finansowania ich składek ubezpieczeniowych ${ }^{14}$. Istotnym jest, że prawo do urlopu wychowawczego wynika z faktu podlegania pod stosunek pracy, co oznacza, że pracownica nie ma obowiązku wykorzystać urlopu macierzyńskiego i rodzicielskiego, aby mogła skorzystać z urlopu wychowawczego. Jest to urlop całkowicie niezależny od dwóch wcześniejszych. Prawo do urlopu wychowawczego przysługuje pracownikowi, którego staż pra-

\footnotetext{
${ }^{12} \mathrm{http} / / /$ zus.pl/files/Komentarz\%20chorobowy\%202016.pdf (dostęp: 01.11.2016).

${ }^{13}$ K. Jaśkowski, E. Maniewska, op. cit.

${ }^{14}$ D. Dzienisiuk, op. cit., s. 158.
} 
cy u danego pracodawcy wynosi przynajmniej 6 miesięcy. Ważnym jest, aby pamiętać, że urlop wychowawczy można wykorzystać maksymalnie do końca roku kalendarzowego, w którym dziecko ukończy 6 lat. Kolejnym udogodnieniem ze strony pracodawcy jest możliwość wykorzystania urlopu wychowawczego w częściach, które nie muszą przypadać po sobie, natomiast może ich być maksymalnie pięć. Ustawodawca w tym przypadku nie zapomniał o właścicielach firm, których dorobek mógłby ulec dezorganizacji poprzez udzielenie kilkunastu części urlopu wychowawczego jednej pracownicy ${ }^{15}$.

W trakcie urlopu macierzyńskiego, jak i urlopu rodzicielskiego pracownicy przysługuje zasiłek macierzyński, który może być przyznany w dwóch wariantach: jeżeli pracownica złoży wniosek o przyznanie jej urlopu rodzicielskiego bezpośrednio po urlopie macierzyńskim, to wtedy przez 52 tygodnie będzie otrzymywała $80 \%$ podstawy wymiaru świadczenia. Natomiast jeżeli pracownica złoży wniosek dopiero przed samym urlopem rodzicielskim - wtedy też przez pierwsze 20 tygodni zasiłek będzie wypłacany w wysokości $100 \%$, a następnie kolejne 32 tygodnie w wysokości $60 \%$. Istotnym jest, aby pracownica miała świadomość jak ważne jest przestrzeganie terminów na złożenie odpowiedniego wniosku.

Znacząca dla poczucia bezpieczeństwa kobiet jest szczególna ochrona trwałości stosunku pracy w czasie ciąży oraz podczas przebywania na urlopie macierzyńskim. Pracodawcę obowiązuje zakaz wypowiedzenia umowy o pracę, jak również rozwiązania już obowiązującego wypowiedzenia. Bardzo ważnym jest, że pracownica nie ma obowiązku udowadniać swojego stanu zdrowia - najważniejszy jest faktycznie istniejący stan rzeczy w chwili rozwiązania lub wypowiedzenia umowy o pracę. Jednakże i w przypadku tej szczególnej ochrony istnieją wyjątki. Wypowiedzenie umowy objętej ochroną może nastąpić m.in. w sytuacji upadłości lub likwidacji pracodawcy, jak również zwolnienia dyscyplinarnego pracownicy. Niezależnie od rodzaju umowy o pracę, pracownice będące w ciąży, jak również te przebywające na urlopach macierzyńskich mają zagwarantowaną ochronę przed wypowiedzeniem zmieniającym, które dla pracodawcy mogłoby być sposobem na ominięcie ochrony stosunku pracy. Dodatkowo pracownica, która złoży wypowiedzenie umowy o pracę, nie wiedząc w tym czasie, że jest w ciąży, ma możliwość uznania, że było to błędne oświadczenie i w ten sposób uchylić się od skutków prawnych złożonego wypowiedzenia. Jednakże nie tylko matki są objęte tą szczególną ochroną. Ochrona przed wypowiedzeniem umowy o pracę przysługuje również pracownikowi-ojcu, który korzysta z urlopu macierzyńskiego. W sytuacji, gdy pracodawca spróbuje ominąc ochronę przysługującą pracownikowi i rozwiąże umowy o pracę - $\mathrm{w}$ świetle prawa pracy będzie przysługiwało takiemu pracownikowi roszczenie o przywrócenie do pracy na wcześniej zajmowane stanowisko, jak również

${ }^{15}$ M. Kuba, op. cit., s. 261. 
możliwość zasądzenia wypłaty wynagrodzeń przysługujących za okres pozostawienia bez posady ${ }^{16}$. Jednakże nie wolno zapominać, że rozwiązanie umowy o pracę na mocy porozumienia stron jest jak najbardziej możliwe.

Do niekwestionowanej sfery prawa pracy należą wszelkiego rodzaju wnioski, w tym również wnioski o urlopy związane z rodzicielstwem. Patrząc na charakter prawny takiego wniosku, można zauważyć, iż przy jego składaniu bardzo ważna jest kwestia decyzji pracodawcy, czy zostanie przez niego wyrażona zgoda, odmowa, czy też trzeba będzie ustalić więcej szczegółów. Warto zauważyć, iż wniosek złożony po terminie nie będzie rodził żadnego obowiązku ze strony pracodawcy, jednakże pracodawca sam z własnej woli może się do niego przychylić. Powyższego charakteru wniosku nie można przełożyć na grunt ubezpieczeń społecznych, ponieważ wnioski składane przez ubezpieczonych dążą do osiągnięcia określonego skutku prawnego, jakim jest np. przyznanie prawa do zasiłku czy powstanie obowiązku ubezpieczenia ${ }^{17}$.

\title{
Bibliografia
}

\section{Literatura}

Dzienisiuk D., Prawo pracy a prawo ubezpieczeń społecznych, Warszawa 2016.

Jackowiak U., Sytuacja pracownicza kobiet, Lex 1994.

Jaśkowski K., Maniewska E., Kodeks pracy. Tom I. Komentarz. Ustawy towarzyszace z orzecznictwem. Europejskie prawo pracy z orzecznictwem, wyd. X, Wolters Kluwer 2016.

Kuba M. [w:] Góral Z. (red.), Urlopy Pracownicze, Warszawa 2016.

Matuszewska A., Piecyk K., Urlopy pracownicze i inne zwolnienia od pracy, Warszawa 2007.

Świątkowski A. M., Kodeks pracy, Komentarz, Warszawa 2016.

\begin{abstract}
Akty prawne
Rozporządzenie Rady Ministrów z dnia 10 września 1996 r. w sprawie wykazu prac wzbronionych kobietom, Dz.U. z 1996. Nr 114, poz. 545 ze zm.
\end{abstract}

Ustawa z dnia 26 czerwca 1974 r. Kodeks pracy, Dz.U. z 1974, Nr 24, poz. 141, ze zm.

\section{Źródła internetowe}

http://zus.pl/files/Komentarz\%20chorobowy\%202016.pdf (dostęp: 01.11.2016).

\footnotetext{
${ }^{16}$ A. M. Świątkowski, Kodeks pracy. Komentarz, Warszawa 2016, s. 936-939.

${ }^{17}$ D. Dzienisiuk, op. cit., s. 333.
} 